колледжа, но и других образовательных организаций среднего профессионального образования республики. Для повышения качества образования необходимо учитывать требования и пожелания не только обучающихся и их родителей, но и работодателей и государства в целом.

Родители играют существенную роль в выборе образовательной организации, так как от их информации о будущей специальности детей и финансовых ресурсов частенько зависит поступление в ту или другую образовательную организацию среднего профессионального образования.

В небольших городах все учебные заведения, будь то образовательные организации среднего профессионального, то ли высшего образования, находятся в положении жёсткой конкуренции. Поэтому родители нацелены на имидж той или иной образовательной организации, на информацию, полученную от других родителей. Отсюда следует, что родители обучающихся являются немаловажным звеном образовательных отношений и тем самым оказывает существенное влияние на положение колледжа на рынке образовательных услуг.

$$
* * *
$$

1. Корнев В.Т. Сущность и содержание понятий «качество образования», «мониторинг качества образования», «управление качеством образования» // Некоторые вопросы анализа, алгебры, геометрии и математического образования. - 2015. - С. 98-100.;

2. Лаптев В.В. Научный подход к построению программ исследования качества образования // Модернизация общего образования на рубеже веков. - СПб.: Изд-во РГПУ им. Герцена, 2001. - С. 3-10.,

3. Нужина В.Н. Стратегия и тактика управления качеством образования. - Иваново: Издательство «Иваново», 2006. -238 c.;

4. Татарченкова С.С. Проблемы качества образования и их решения в образовательном учреждении. - СПб.: Каро, 2012. - 120 с. и др.

5. Рагозинникова Л.Н. Оценка качества образования глазами обучающихся, родителей и педагогов // Инновационные проекты и программы в образовании. - 2012. №1 Режим доступа: http: // cyberleninka.ru/article/n/otcenka-kachestva-obrazovaniya-glazami obuchayuschihsya-roditeley-i-pedagogov (дата обращения: 15.09.2018);

6. Панасюк В.П. Педагогическая система внутришкольного управления качеством образовательного процесса: дис. д-ра пед. наук. - СПБ., 1998. 460 с.;

7. Федеральный закон № 273 «Об образовании в Российской Федерации»

\title{
Роговая Н.А. \\ Анализ становления профессионально ориентированного иностранного языка (ESP) как вузовской дисциплины
}

Дальневосточный Федеральный Университет

(Россия, Владивосток)

doi: 10.18411/trnio-11-2021-177

\section{Аннотация}

В статье представлен анализ становления междисциплинарной теории и практики иноязычной профессиональной подготовки выпускников вуза, обосновывается необходимость разработки и внедрения в учебный процесс курса «English for Specific Purposes».

Ключевые слова: профессиональная подготовка, иностранный язык для специальных целей, профессионально-ориентированный, профессиональная деятельность, обучение.

\section{Abstract}

The article is devoted to the analyses of interdisciplinary theory and practice formation of foreign language professional training of technical students. The development and implementation of the "English for specific purposes" course is proved.

Keywords: professional training, foreign language for specific purposes, professional activities, education. 
При проектировании системы профессиональной подготовки исходным пунктом выступает анализ накопленного опыта решения исследуемой проблемы в зарубежной и отечественной педагогической теории и практике. На разных этапах развития профессионального образования проблема интеграции и взаимодействия иноязычной коммуникации и профессиональной деятельности всегда интересовала исследователей.

В настоящий период в теории и практике преподавания иностранных языков в системе высшего профессионального образования усилилась тенденция ориентации на обучение профессиональному иностранному языку, на разработку технологий обучения в соответствие с концепцией овладения иностранным языком в контексте профессиональной деятельности. Отечественная и зарубежная лингвистика, педагогика и методика преподавания иностранных языков в качестве основного подхода к построению образовательных систем использует идею обучения языкам для специальных целей (Language for specific purposes) как одному из приоритетных направлений. Научное обоснование любой концепции основывается на историко-логическом анализе, который позволяет проследить развитие теории и практики обучения, учесть лучший зарубежный и отечественный опыт, понять современные тенденции и выявить перспективы развития.

История преподавания иностранных языков, с учетом специфики профессиональной деятельности обучающихся, берет свое начало в середине прошлого столетия, появлением в начале 50-х годов XX века «английский для специальных целей» в Великобритании и Америке, было обусловлено обстоятельствами, характерными для данного периода развития общества [2] , а именно- необходимостью языковой подготовки большого количества иностранных студентов для обучения в британских и американских университетах и эмигрантов, для которых владение английским языком служило гарантией их трудоустройства. В англо-, германо- и славяноязычной лингвистике почти одновременно возникает необходимость к языку профессиональной сферы общения как к феномену и, как следствие, рождаются соответствующие номинации: English for Specific Purposes (ESP) - a американской литературе, Fachsprachen - в германоязычной литературе [9].

Основное принципиальное отличие ESP от общего английского языка заключается в акцентировании внимания педагогов и методистов на образовательных потребностях лиц, изучающих иностранный язык [7]. На тех целях, для реализации которых необходимы навыки владения иностранным языком. На этом положении основывается определение ESP, сформулированное Т.Хатчинсоном и А. Уотерсом. Они рассматривают ESP как подход к преподаванию английского языка, при котором все решения относительно содержания и методов основываются на причинах, побуждающих к изучению иностранного языка. ESP видится, не как подготовка к сдаче традиционных экзаменов, а как овладение языковыми навыками, необходимыми для работы и учебы. ESP рассматривается этими методистами как язык определенной сферы профессиональной деятельности, содержательная сторона которой варьируется в зависимости от области его применения [10].

Джон Майнби указывает на приоритетность анализа коммуникативных потребностей обучающихся при планировании профессионально-ориентированных курсов, а Джо Мак Доноу считает ESP отдельной областью преподавания иностранного языка с собственным методологическим аппаратом.

Огромное внимание разработчики концепции «интерактивного языка для специальных целей» уделяли методологии. Однако, если Ундоусон, Хатчинсон и Уотерс сходились на центральной роли методологии, но фундаментально расходились в вопросе о ее характере. Ундоусон считал, ESP неразрывно связан с областью деятельности, представляющими стремления обучающихся и, следовательно, является зависимым процессом, из чего следует, что и педагогика ESP также зависит от основной предметной области. Хатчинсон и Уотерс, со своей стороны, не видели теоретических различий между ESP и преподаванием общего курса, единственное различие прослеживалось в практической деятельности. Существовали также и определенные разногласия по вопросу нужна или нет 
специальная предметно-ориентированная подготовка преподавателей иностранных языков для работы со специалистами различных профессиональных сфер.

Т. Джонс и Т.Дудли-Эванс [9] отмечали, что в такого рода сотрудничестве всегда задействованы три стороны: преподаватель иностранного языка, преподаватель специальной дисциплины и сам студент. Задачах сторон данного треугольника состоит в поиске путей создания оптимальных отношений внутри него для обеспечения успешного обучения. Если работа преподавателей разных дисциплин осуществляется изолированно друг от друга, то «знание предмета» и «знание языка» не находят точки соприкосновения. Каждый участник треугольника нуждается в определенной помощи и обратной связи. Студенту нужно знать, как оцениваются результаты его деятельности и совпадают ли они с ожиданиями преподавателей. Преподаватель-предметник должен иметь четкое представление, насколько эффективно он общается со студентами и как эта коммуникация может быть улучшена [6]. Преподаватель иностранного языка должен быть в состоянии «ухватить» концептуальную структуру изучаемой его студентами науки, так как ему предстоит понять, как используется иностранный язык в определенной профессиональной деятельности. Кроме того, сотрудничество между участниками этого треугольника может создать релевантную коммуникативную ситуацию для использования навыков ESP [3].

Дж. Эвер предлагает введение специальной схемы подготовки преподавателей на последнем курсе факультета иностранных языков с ориентацией на одну или несколько областей науки, технологии или бизнеса.

Другие практики ESP считают, что цель преподавания иностранных языков - научить пользоваться языком как инструментом разрешения коммуникативных проблем, а не фокусироваться на возможности его применения в качестве лингвистического отражения определенной предметной области $[1,4,5]$.

Современная теория и практика преподавания иностранного языка курс ESP применяется при обучении иностранному языку магистрантов и аспирантов, где прежде всего, весь учебный процесс ориентирован на удовлетворение специфических потребностей обучающихся. В этом контексте ESP рассматривается как язык повседневного общения, используемый для максимально точного описания определенной области знаний или деятельности [8]. То есть, этот язык является обычным языком, выполняющим когнитивную функцию, отражающую развитие цивилизации. И служащую в качестве инструмента профессиональной деятельности обучения.

Определенным слабым местом курса ESP может считаться недостаточный учет потребностей государства и общества при определении цели и содержания языковой подготовки специалистов, разноплановость в выделении методологических подходов при проектировании образовательных систем, определенные трудности в разработке комплексных обучающих образовательных программ в соответствие с отраслевым делением.

Тем не менее, курс ESP можно рассматривать в качестве прообраза компетентностного подхода к преподаванию иностранного языка, поскольку этот подход нацелен на создание условий профессионального становления и развития специалиста, при которых иностранный язык в системе высшего образования выступает не как самоцель, а как средство достижения профессиональной зрелости и формирования качеств, необходимых для успешного функционирования в избранной области.

$$
* * *
$$

1. Вербицкая А.А. Иноязычное образование в контексте профессии // Вестник московского государственного лингвистического университета. Образование и педагогические науки., №2(796), 2018, с. 126-141.

2. Гумовская Г.Н. Физика. Первое сентября. 2007, №1, -с.15.

3. Еремина Н.В., Томин В.В., Богомолова А.Ю. Взаимодействие и развитие иноязычной речевой деятельности студентов нелингвистических специальностей // Мир науки, Том 4 №2, 2016, с.14.

4. Карабутова Е.А., Прокопенко Ю.А. Обучение студентов неязыковых специальностей иноязычному профессиональному дискурсу как основа эффективного формирования иноязычной коммуникативной компетенции // Мир лингвистики и коммуникации: электронный научный журнал, №41, 2015, c. 44-54. 
5. Крупченко А.К. К вопросу профессиональной лингводидактике// Современная теория и методики обучения иностранным языкам/ - М.: Экзамен, 2004. - с.243.

6. Куклина С.С. Учебная деятельность по овладению иноязычным общением и ее организационные формы // Монография, изд. ВГГУ г.Киров, 2013, - 175с.

7. Локтюшина Е.А. Об изменении требований к профессиональной готовности преподавателей иностранного языка // Научное обеспечение системы повышения квалификации кадров, №2 (15), 2013, с. 12-17.

8. Минакова П.С., Роговая Н.А., Шегай Л.А. Развитие навыков профессиональной иноязычной коммуникации у студентов технических направлений // Современные технологии и методики эффективного обучения иностранным языкам, сборкик материалов он-лайн форума, 2021, с.47-52.

9. Dudley - Evans T. Development in ESP: A Multi-disciplinary Approach $\backslash$ T. Dudley- Evans, M.St.John.- Cambridge: Cambridge University Press, 1998

10. Hutchinson T. English for Specific Purposes: A Learning-centered Approach $\backslash$ T. Hutchinson, A. waters. Cambridge: Cambridge University Press. 1987.

\section{Рябченко Н.Н. \\ Формирование лингвоэкологической компетентности учащихся в процессе обучения русскому языку}

ГБОУ ВО «Ставропольский государственный педагогический институт»

(Россия, Ставрополь)

doi: 10.18411/trnio-11-2021-178

\section{Аннотация}

В статье рассматривается специфика формирования лингвоэкологической компетентности обучающихся в практике школьного обучения русскому языку. Автор раскрывает условия формирования лингвоэкологической компетентности у обучающихся, дает описание методов работы, содействующих повышению речевой культуры учащихся, рассматривает систему упражнений, ориентированных на овладение учениками нормами русского литературного языка и обогащение словарного запаса. Статья предназначается для педагогических работников, желающих познакомиться с особенностями формирования лингвоэкологической компетентности обучающихся на уроках русского языка.

Ключевые слова: лингвоэкологическая компетентность, русский язык, языковые нормы русского литературного языка, словарный запас.

\section{Abstract}

The article examines the specificity of the formation of linguo-ecological competence of students in the practice of school teaching of the Russian language. The author reveals the conditions for the formation of linguo-ecological competence in students, gives a description of the methods of work that contribute to improving the speech culture of students, considers a system of exercises aimed at mastering the norms of the Russian literary language by students and enriching the vocabulary. The article is intended for teachers who want to get acquainted with the peculiarities of the formation of linguo-ecological competence of students in the lessons of the Russian language.

Keywords: linguo-ecological competence, Russian language, linguistic norms of the Russian literary language, vocabulary.

В условиях современной школы перед учителем стоит глобальная задача подготовить культурного, высокообразованного человека, творческую личность. Решение обозначенной задачи ориентировано на создание благоприятной языковой и речевой среды, влияющей на духовное развитие ученика, речевую культуру, формирующую его лингвоэкологическую компетентность. Формирование лингвоэкологической компетентности учащихся - это воздействие на языковое и речевое развитие ученика, обучение его правильному речевому поведению. 